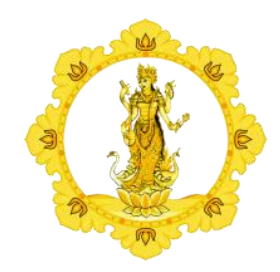

KALANGWAN

JURNAL PENDIDIKAN AGAMA, BAHASA DAN SASTRA

Vol. 10 No. 1 Maret 2020

\begin{tabular}{|c|c|l|}
\hline p-ISSN : 1979-634X & e-ISSN : 2686-0252 & http://ejournal.ihdn.ac.id/index.php/Kalangwan
\end{tabular}

\title{
TUJUAN HIDUP DALAM KACAMATA KITAB SARASAMUCCAYA
}

\author{
Oleh : \\ Anak Agung Gede Wiraputra \\ Institut Hindu Dharma Negeri Denpasar \\ E-mail: agungwira9706@gmail.com
}

Diterima 25 Januari 2020, direvisi 12 Pebruari 2020, diterbitkan 31 Maret 2020

\begin{abstract}
Veda is the scripture of Hinduism religion. In addition to the Vedic scriptures, Hinduism also knows what is called the smrti scripture. Sarasamuccaya is part of smerti scripture which rich in moral values in it. One of the moral value in the scripture of Sarasamuccaya is Catur Purusartha or Catur Warga which is known as the four goals of human life, such as dharma (truth), artha (wealth/purpose), kama (lust/desire), and moksa (the ultimate goal/deliverance). The purpose of this paper is to uncover the teaching of Catur Purusartha or Catur Warga contained in the scripture of Sarasamuccaya with device in the form of structural and religion theorys supported by content analysis and descriptive analysis methods. The results of the analysis show that the basic purpose of human life is essentially to always try to do good and help yourself from suffering, so as to realize a better life. The discussion of the purpose of life (Catur Purusartha or Catur Warga) in the scripture of Sarasamuccaya, such as: the dharma outlined in the majesty of dharma segments, the source of dharma, and the implementation of dharma. Artha is elaborated through the primacy of world funds. Kama or lust is described in the discussion of kama (lust) and naughty women. Finally, the doctrine of deliverance (moksa) is described in the concepts and nature of the wise. The whole discussion is a practical guide that is very useful for realizing primary life.
\end{abstract}

Keywords: Sarasamuccaya, Catur Purusartha, and Life Goals. 


\section{PENDAHULUAN}

Dalam ajaran agama Hindu, terdapat berbagai pustaka yang merupakan turunan kitab suci Weda sebagai sumber pengetahuan agama Hindu yang paling tinggi. Istilah untuk turunan kitab Suci Weda tersebut adalah kitab smerti atau dapat disebut dengan dharmasastra. Sebagai turunan dari Weda, kitab smerti juga menjadi sumber ajaran agama Hindu selain sila/tingkah laku yang suci, acara/tradisi yang baik, dan atmanastuti/keheningan hati (Titib, 1996: 29). Kitab smerti merupakan pustaka yang masih berorientasi pada Weda, hanya saja pembahasannya lebih mendetail pada ulasan tertentu dan dikemas dalam bahasa serta sistematika yang lebih sederhana. Salah satu dari ribuan kitab smerti adalah kitab Sarasamuccaya buah karya Bhagawan Wararuci. Sarasamuccaya merupakan pustaka suci yang membahas mengenai segala sesuatu terkait dengan pelaksanaan susila dalam kehidupan. Selain hal tersebut dalam Sarasamuccaya juga sedikit menyinggung mengenai tinjauan filosofis, maupun acara sebagai petunjuk dalam menjalani kehidupan. Keseluruhan ajaran tersebut disajikan dalam 517 sloka dengan 27 sub pembahasan, sehingga menjadikan kitab Sarasamuccaya sebagai pedoman praktis menuju hidup yang lebih baik (Sudharta, 2009: v).

Menyinggung mengenai berbagai ajaran susila keagamaan, salah satu ajaran spesifik yang terdapat dalam kitab Sarasamuccaya adalah terkait dengan Catur Purusartha atau Catur Warga. Catur Purusartha adalah empat tujuan utama dalam kehidupan umat Hindu yang terdiri dari dharma, artha, kama, dan moksa (Sudharta, 2009: 4). Keempat hal tersebut adalah sesuatu yang sangat berguna dan menjadi tujuan hidup manusia, sehingga dalam kehidupan ini, semua manusia sangat mengusahakan agar senantiasa mendapatkan dharma (kebenaran), artha (harta/kekayaan), kama (pemenuhan keinginan/nafsu), dan moksa (tujuan akhir agama Hindu/menyatunya atman dengan brahman). Keseluruhan tujuan tersebut tentunya harus ditempuh dengan cara yang baik dan benar (subha karma), sehingga hakikat kehidupan dapat tercapai, yaitu melebur karma buruk ke dalam karma baik. Namun, kenyataannya dalam kehidupan saat ini terkadang semua tujuan hidup dicapai dengan menghalalkan segala cara, sehingga esensi hidup untuk memperbaiki karma terdahulu malah menjadi menambah karma tidak baik. Contoh: mencari uang dengan cara korupsi, memuaskan nafsu birahi dengan jalan menyelingkuhi istri atau suami orang lain, maupun memenuhi tujuan hidup lainnya dengan cara yang melanggar ketentuan agama.

Berdasarkan penyimpangan cara pemenuhan tujuan hidup di atas, penulis memandang perlu adanya pelurusan terkait dengan pemenuhan tujuan hidup (Catur Purusartha) agar senantiasa tercapai dengan baik dan benar. Tujuan hidup tersebut tidak hanya perlu untuk dicapai, namun cara pencapaiannya juga harus benar, sehingga hasilnyapun juga tidak menyimpang dari ajaran agama. Oleh karena itu, penulis merasa tertarik untuk mengangkat terkait dengan pemenuhan tujuan hidup yang baik dan benar sesuai dengan sabda kitab Sarasamuccaya. Pelurusan tersebut bertujuan untuk memberikan pencerahan terkait esensi tujuan hidup dan jalan yang benar untuk mencapai tujuan tersebut. Keseluruhan gagasan tersebut penulis sajikan dalam sebuah karya ilmiah berbentuk artikel jurnal ilmiah yang berjudul: "Tujuan Hidup dalam Kacamata Kitab Sarasamuccaya".

\section{PEMBAHASAN \\ 2.1 Dasar Tujuan Hidup (Catur Purusartha) menurut Kitab Sarasamuccaya}

Dalam kehidupan dewasa ini, sangat banyak orang-orang yang merasa bahwa mereka telah mencapai segala macam tujuannya dan tidak sadar akan cara yang dilalui adalah cara yang salah. Bahkan ada yang bangga dan terkenal akibat mengejar tujuan hidup dengan cara yang salah. Contohnya: Para selebritis yang berlombalomba membuat sensasi hanya untuk memuluskan tujuannya, yaitu semakin terkenal, sering diundang ke acara TV, dan tentunya akan banyak mendapatkan bayaran. 
Selain itu, banyak orang yang mencari kekayaan dengan jalan korupsi, kolusi, nepotisme, merampok, mencuri, dan lain sebagainya. Secara kasat mata, mereka memang terlihat kaya, namun pada hakikatnya mereka tidaklah mencapai kekayaan dengan jalan yang benar. Di sisi lain, juga terdapat orang-orang yang memuskan nafsu birahinya dengan cara yang salah, seperti dengan berhubungan badan dengan saudara atau orang tua, selingkuh dengan istri atau suami orang lain, maupun cara lain yang menyalahi aturan agama. Contoh-contoh di atas sangat marak terjadi di zaman sekarang, karena masyarakat sebagian besar sudah tidak menghiraukan mana yang semestinya dan mana yang tidak semestinya dilakukan. Tuntutan yang semakin banyak dan hidup yang semakin keras membuat orang-orang mulai terbiasa dan mentoleransi perbuatan curang serta melanggar ajaran agama demi mempertahanakan hidupnya. Agama hanya dijadikan identitas diri semata tanpa mau menggali lebih dalam hakikat kehidupan yang terdapat dalam ajaran agama. Perbuatan-perbuatan seperti demikian adalah perbuatan yang hanya dilandasi oleh nafsu dan keserakahan semata yang akan membawa manusia menuju ke gerbang neraka (Titib, 2011: 7).

Pada hakikatnya, setiap kitab suci agama apapun pastinya menyetujui bahwa manusia merupakan mahluk ciptaan Tuhan yang paling sempurna. Sempurna dalam hal ini adalah manusia memiliki bawaan yang paling lengkap, baik dari segi fisik maupun psikisnya (lahir maupun batin) apabila dibandingkan dengan binatang maupun tumbuh-tumbuhan. Oleh karena itu, manusia adalah mahluk yang mampu melakukan perbuatan yang paling kompleks, karena telah mempunyai tenaga untuk berbuat, mampu mengungkapkan isi hati melalui bahasa, dan mampu berpikir terkait apa yang akan dilakukan dengan logika yang dimiliki. Ketiga hal tersebut dalam ajaran agama Hindu disebut dengan Tri Pramana, yaitu bayu (kekuatan/tenaga), sabda (kemampuan berbicara), dan idep (pikiran). Selain hal tersebut, pikiran manusia juga mampu membedakan antara mana yang baik dan mana yang buruk, sehingga dengan kemampuan tersebut manusia mampu mengendalikan diri untuk selalu berpikir, berkata, dan berbuat yang baik. Dalam ajaran agama Hindu, alarm dalam pikiran manusia yang mambedakan antara hal yang baik dan buruk tersebut dinamakan wiweka.

Dengan adanya kelebihan yang tiada tara tersebut, kitab Sarasamuccaya pun mengakui bahwa hidup menjadi manusia adalah sesuatu yang sangat beruntung, karena sungguhlah sulit untuk mendapatkan kesempatan untuk hidup dan menjelma menjadi seorang manusia. Hal tersebut tertuang dalam sloka 4 yang berbunyi:

Apan iking dadi wwang, uttama juga ya, nimittaning mangkana, wěnang ya tumulung awaknya sangkeng sangsara, makasādhanang śubhakarma, hinganing kottamaning dadi wwang kita.

\section{Terjemahan:}

Sesungguhnya menjelma sebagai manusia ini adalah satu hal yang utama, karena hanya manusialah yang dapat menolong dirinya sendiri dari kesengsaraan, yaitu dengan jalan berbuat baik. Itulah keuntungan menjelma menjadi manusia (Sudharta, 2009: 5).

Berdasarkan sabda kitab Sarasamuccaya sloka 4 di atas, kelebihan manusia yang amat utama adalah kemampuannya untuk menyelamatkan diri dari kesengsaraan dengan jalan berbuat yang baik. Pada hakikatnya, kelahiran kembali ke dunia ini adalah untuk membayar karma yang telah dilakukan pada kehidupan sebelumnya. Apabila manusia mampu selalu berbuat baik (subha karma) semasa hidupnya, maka ia akan terlepas dari penderitaan dan menuai kebahagiaan abadi yang tidak akan kembali menemui kesengsaraan atau dikenal dengan istilah sat cit ananda, baik di dunia maupun akhirat. Oleh karena itu, sekecil apapun perbuatan baik yang dilakukan manusia, akan sangat utama apabila dibandingkan dengan 
hidup bahagia dari hasil perbuatan yang tidak baik.

Kadang kala banyak sekali orang yang menyesal akan hidupnya, karena miskin, kurang cerdas, cacad fisik, dan berbagai kekurangan lainnya yang membuat manusia menjadi putus asa. Namun, semenderita apapun kehidupan di dunia, manusia hendaknya selalu bersyukur dan maneguhkan budi, karena sangatlah utama dapat dilahirkan sebagai manusia, meski hidup merana sekalipun. Kehidupan di dunia ini pada dasarnya adalah tangga untuk mencapai surga, sehingga harus selalu dimanfaatkan untuk berbuat yang baik. Hendaknya manusia tidak pernah jemu-jemu untuk selalu berpikir, berkata, dan berbuat yang baik. Itulah yang menjadi hakikat dan tujuan hidup manusia, yaitu manusia hidup dan diciptakan di dunia untuk menikmati karma wasana (sisa hasil perbuatan atau sisa bau perbuatan) terdahulu dan berkewajiban untuk melebur perbuatan jahat ke dalam perbuatan yang baik. Sebenarnya tujuan hidup manusia di dunia ini amat sederhana, namun sangatlah susah untuk mewujudkan sebagai akibat dari kegelapan (awidya) yang meliputi diri manusia, sehingga diperlukan niat dan keteguhan hati agar senantiasa lolos dan mampu berbuat yang baik di segala kesempatan atas dasar tulus ikhlas tanpa pamrih.

\subsection{Pandangan Tujuan Hidup (Catur Purusartha) menurut Kitab Sarasamuccaya}

Kitab Sarasamuccaya merupakan gudangnya ajaran susila keagamaan yang dimiliki oleh umat Hindu. Salah satu konsep yang terkandung di dalamnya adalah terkait dengan tujuan hidup yang disebut dengan Catur Purusartha atau Catur Warga. Catur Purusartha berasal dari tiga kata dalam bahasa Sanskerta, yaitu catur yang berarti empat, purusan yang berarti jiwa, dan artha yang berarti tujuan. Hal tersebut sejalan dengan Catur Warga yang terdiri dari dua kata dalam bahasa Sanskerta, yaitu catur berarti empat dan warga artinya golongan yang terjalin erat. Jadi, Catur Purusartha atau Catur Warga adalah empat tujuan hidup yang terjalin erat.
Adapun bagian-bagiannya terdiri dari dharma/kebenaran, artha/harta/tujuan, kama/nafsu, dan moksa/tujuan akhir (Sudharta, 2009: 4). Ajaran Catur Purusartha dalam kitab Sarasamuccaya bahkan telah disinggung pada bagian awal yang disebut sebagai prakata pada sloka pertama sebagai berikut:

Anaku kamung Janamejaya,
salwirning warawarah, yāwat
makapadārthang caturwarga,
sāwataranya, sakopanyāsanya, hana
juga yangke, sangșepanya, ikang
hana ngke, ya ika hana ing len
sangkeriki, ikang tan hana ngke, tan
hana ika ring len sang keriki.
Terjemahan:
Anakku, engkau Janamejaya, segala
ajaran-ajaran kerohanian, demikian
juga ajaran Catur Warga (artha, kama,
dharma, moksa), baikpun sumber
maupun perkembangannya hanya ada
disini. Artinya, segala yang terdapat
disini akan terdapat juga di tempat lain
dan yang tidak ada disini akan tidak
ada di tempat yang lain dari sini
(Sudharta, 2009: 4).

Dalam petikan sloka tersebut dijelaskan bahwa ajaran Catur Warga atau Catur Purusartha pada dasarnya terdapat di dalam kitab Sarasamuccaya dan di semua kitab Weda lainnya, karena segala hal yang terdapat di dalam Sarasamuccaya juga akan terdapat di sumber lainnya. Begitu juga yang tidak terdapat di dalam kitab Sarasamuccaya juga tidak akan dapat dijumpai di tempat lain. Secara tidak langsung, pernyataan tersebut mengisyaratkan bahwa seluruh pustaka suci Weda saling terkait antara satu dengan yang lainnya. Oleh karena itu, segala hal yang terdapat dalam Sarasamuccaya, termasuk ajaran Catur Purusartha akan terdapat juga dalam susatra Weda lainnya, hanya saja tersaji dalam sistematika pembahasan yang berbeda.

$$
\text { Terkait dengan ajaran Catur }
$$

Purusartha atau Catur Warga, kitab 
Sarasamuccaya memberikan pemaparan secara rinci sebagai berikut:

\subsubsection{Dharma}

Secara etimologi, dharma berarti hukum, kebiasaan, kealiman, kebajikan, aturan, kebenaran, tugas, keadilan, jasa, dan karakter (Surada, 2007: 169). Dharma juga berarti hak dan kewajiban hidup (Mardiwarsito, 1986: 171). Jadi, dharma pada dasarnya merupakan segala sesuatu yang benar sesuai dengan aturan dan hukum, baik secara lahir maupun batin. Kitab Sarasamuccaya secara rinci membahas mengenai dharma dengan tajuk keagungan dharma, sumber dharma, pelaksanaan dharma. Pada pembahasan tersebut dituliskan bahwa sebenarnya untuk mendapatkan harta dan nafsu, dharmalah yang pertama harus dilakukan, karena apabila dharma sudah dilakukan, maka harta dan kepuasan nafsu akan terpenuhi. Jadi, sangatlah tidak baik apabila mendapatkan harta dan kepuasan nafsu di luar jalan dharma. Dengan dharma, para pelaksananya akan mendapatkan kebahagian yang sejati. Dharma merupakan alat yang digunakan untuk mencapai surga, seperti perumpamaan perahu yang digunakan untuk melintasi samudera nan luas. Orangorang yang melaksanakan dharma diibaratkan sebagai matahari yang menghilangkan kegelapan hidup, sama halnya orang-orang yang selalu berbuat dharma akan menghilangkan segala penderitaan. Tidak peduli tinggi atau rendah kedudukan orang itu, apabila di dalam hatinya selalu bersemayam dharma, maka pasti akan selalu tercapai semua keinginannya. Orang yang berbuat dharma bagaikan air yang menggenangi tempat tumbuhnya tanaman tebu, bukan hanya tebu saja yang terkena air, tetapi rumput dan segala macam tumbuhan yang ada di sana juga akan merasakan sejuknya air. Sama dengan orang yang berbuat dharma, tanpa diharapkan sekalipun, maka secara otomatis dia akan diikuti oleh harta, kesuburan, dan kemasyuran (Sudharta, 2009: 8-12).

Perbuatan dharma yang dilakukan oleh seseorang tidak hanya akan mendatangkan kebahagiaan di dunia fana ini, namun juga akan berpengaruh terhadap kehidupannya di masa yang akan datang, seperti pada petikan kitab Sarasamuccaya sloka 21 sebagai berikut:

\section{Kunang ikang wwang gumawayikang śsubhakarma, janmanyan sangkě rig swarga dèlāha, litu hayu maguña, sujanma, sugih, mawīrya, phalaning śsubhakarmāwasāna tinèmunya. \\ Terjemahan:}

Adapun orang yang melakukan perbuatan yang baik (benar), ia di kelak kemudian hari akan menjelma dari surga, menjadi orang yang tampan dan cantik, gunawan, berkedudukan tinggi, kaya raya, dan bersifat pahlawan. Itulah yang didapatinya sebagai phala dari hasil perbuatannya yang baik (Sudharta, 2009: 12).

Petikan sloka di atas mengisyaratkan bahwa dharma merupakan hal yang tidak hanya berlaku di dunia, namun kebaikan dharma juga akan ikut dibawa sebagai bekal untuk ke akhirat dan sangat berpengaruh terhadap kelahiran seseorang. Oleh karena itu, tidak heran apabila di dunia ini banyak terdapat orang-orang yang hampir sempurna, baik dari segi fisik maupun psikisnya. Hal tersebut diyakini karena pada kehidupannya terdahulu, orang tersebut selalu berbuat dharma, sehingga ia dilahirkan dari surga dengan berbagai kesempurnaan. Sama juga halnya dengan orang yang di kehidupan saat ini selalu berbuat jahat, tetapi dia selalu mendapatkan keutamaan. Hal tersebut disebabkan oleh di kehidupan terdahulu ia selalu tekun melaksanakan dharma, sehingga hingga kehidupan sekarang ia masih menikmati hasil perbuatan baiknya terdahulu. Untuk perbuatan jahat yang dilakukannya pada kehidupan saat ini, ia akan menanggungnya di kehidupan berikutnya sebagai konsekuensi karma buruk yang dilakukan.

Dalam kitab Sarasamuccaya juga disebutkan bahwa orang yang selalu berbuat 
dharma tidak akan pernah diikuti oleh hal-hal yang membahayakan, sekalipun ia berada di semak-semak, di hutan, di jurang, maupun di segala tempat yang berbahaya dan menimbulkan kesusahan, bahkan di tempat peperanganpun ia tidak akan disentuh oleh bahaya, karena perbuatan baiknya akan selalu melindungi di manapun berada. Waktu untuk mencari harta dan pengetahuan adalah cukup banyak, sedangkan waktu untuk melakukan dharma bagaikan kilatan cahaya, sehingga harus buru-buru dimulai untuk berbuat dharma tanpa menunggu lagi. Selagi umur masih muda, hendaknya selalu diusahakan untuk berbuat dharma. Umur yang muda akan segera berganti menjadi umur tua dan akhirnya umur tersebut akan habis. Oleh karena itu, semasih hayat di kandung badan, dharma haruslah selalu ditegakkan (Sudhatra, 2009: 13-16). Kekuatan dharma akan menyertai di manapun jiwa berada, seperti sloka 32 kitab Sarasamuccaya sebagai berikut:

Apanikang kadang warga rakwa, ring tunwan hingan ikan pangatěrakěn, kunang ikang tumūt, sahāyanikang dadi hyang ring paran, gaweny $\bar{a}$ śubhāsubha juga, matangyan prihěna tiking gawe hayu, sahāyanta antuntunakěna ri pöna dlāha.

\section{Terjemahan:}

Sebab sanak keluarga itu, hanya sampai di pembakaran (di kuburan) batasnya mengantar. Adapun yang ikut sebagai teman bagi jiwa di alam baka adalah perbuatan baik atau buruk itu jualah adanya. Oleh karena itu berusahalah berbuat baik yang akan merupakan sebagai sahabat yang akan menuntun jiwamu ke alam baka kelak (Sudharta, 2009: 16).

Sloka kitab Sarasamuccaya di atas sudah sangat jelas memperingatkan bahwa perbuatan baik adalah sesuatu yang tidak bisa digantikan oleh apapun. Dengan perbuatan baik, manusia akan senantiasa mampu meningkatkan kualitas diri dan mampu mengumpulkan bekal untuk menuju alam nirwana. Karma yang dibuat oleh manusia akan selalu mengikuti kemanapun jiwa pergi. Saat meninggal dunia, sanak saudara dan keluarga hanya bisa menangis dan menemani hingga kuburan saja, selebihnya sang jiwa akan ditemani dan ditentukan arahnya oleh karma baik maupun buruk yang pernah dibuat semasih hidup. Oleh karena itu, manusia tiada henti-hentinya dihimbau agar selalu berbuat yang baik.

Pada dasarnya, semua tujuan hidup akan mengarah kepada dharma, hanya saja setiap orang menggunakan cara yang berbeda-beda. Dharma tidak memandang berasal dari mana, karena ia bisa datang dari utara, selatan, datang dari orang yang lebih tua, maupun datang dari orang yang lebih muda, sehingga tidak ada satupun yang bisa memastikan dari mana arah datangnya dharma. Oleh karena itu, dharma tiada bedanya dengan ular yang bisa datang dari mana saja dan menyusup kapan saja tanpa adanya asas kepastian. Yang dapat dipastikan adalah dharma itu sendiri bersumber dari Weda, baik yang dinamakan Weda Sruti maupun Weda Smerti. Weda dipelajari dengan sempurna melalui itihasa dan purana (sejarah dan cerita kepahlawanan), sehingga akan didapat intisari kebenaran yang sebenarnya. Orang yang tidak pernah mempelajari dan memahami dharma tiada ubahnya seperti sebutir telur busuk, bendanya ada, namun sama sekali tidak berguna. Orang yang senantiasa mengusahakan dharma adalah orang yang disebut sebagai orang kaya, karena dharma adalah kekayaan yang sama sekali tidak bisa dirampas oleh siapapun dan akan menjadi bekal menuju ke alam akhirat yang tenang serta dipenuhi kebahagiaan. Apabila dharma sudah dipegang, maka artha dan kama dapat senantiasa dicari sejalan dengan perjalanan meneguhkan dharma. Peneguhan dharma memang sangat sulit, bagaikan menemukan jejak ikan di air. Namun apabila dilaksanakan dan diusahakan dengan penuh keteguhan, maka senantiasa dharma akan mampu untuk dicapai (Sudharta, 2009: 17-26). Demikianlah hakikat dharma yang terkandung dalam pustaka suci Sarasamuccaya. 


\subsubsection{Artha}

Artha berdasarkan etimologinya berasal dari bahasa Sanskerta yang berarti arti, tujuan, maksud, uang, pemakaian, penggunaan, urusan, perkara, dan kesejahteraan duniawi (Surada, 2007: 42). Artha dapat juga berarti pengertian atau pemahaman akan makna/arti (Mardiwarsito, 1986: 77). Artha secara awam juga dapat diartikan dengan harta. Harta tidak hanya dalam bentuk uang, namun juga dalam bentuk tenaga, ilmu pengetahuan, wajah yang rupawan, umur muda, kebaikan hati, dan bahkan semua yang dimiliki oleh manusia juga dapat disebut sebagai harta. Dalam kitab Sarasamuccaya, salah satu pembahasan yang terkait dengan harta adalah dana punia. Dana punia tidak hanya perihal harta dan kekayaan, namun pertolongan yang tulus kepada orang lain pun termasuk dalam dana punia. Pahala yang didapatkan oleh orang yang melakukan dana punia bukanlah didapatkan oleh Bapak, Ibu, atau sanak saudara dari orang tersebut, melainkan akan didapatkan oleh dirinya sendiri. Pada dasarnya, dana punia sebenarnya adalah hal yang sangat sulit dilakukan, karena umumnya orang-orang merasa sangat sayang dengan harta dan apapun yang dimiliki, sehingga tidak akan rela untuk disumbangkan (Sudharta, 2009: 74-76). Hal tersebut berbeda dengan pemikiran tentang dana punia yang keluar dari orang bijaksana yang dijelaskan oleh kitab Sarasamuccaya sloka 175 , yaitu:

Mangke māra de sang enak wruhṇira, tar tiněngětnira māsṇira, huripnira tuwi, yan pakaphalang kaparamārthan, wruh wi sira ring niyataning pati mwang ri tan hana ning wastu langgěng, matangyan lahěng, ikang winașa makaphalang kapara mārțan.

\section{Terjemahan:}

Sekarang dengarlah perihal orang yang tinggi ilmu kebijaksanaannya, yaitu bahwa ia tidak sayang untuk mengorbankan harta benda, kekayaan, maupun nyawanya sekalipun, apabila untuk kepentingan umum. Sebab ia sadar akan kekekalan jiwa dan tidak kekekalan benda, keadaan lahiriah ini. Oleh karena itu ia lebih baik demi untuk kepentingan umum (Sudharta, 2009: 77-78).

Sloka di atas telah jelas menunjukkan perbedaan pemikiran orang biasa dengan orang yang telah memiliki pengetahuan yang luas dan bijaksana. Di saat orang-orang sibuk mengumpulkan kekayaan untuk diri sendiri, orang yang tinggi ilmu dan bijaksana malahan berlomba-lomba menyumbangkan apa yang dimiliki kepada orang yang membutuhkan, karena telah terdapat kesadaran dalam diri bahwa yang kekal bukanlah harta, namun asas kejiwaan yang telah manunggal menuju ke Sang Pencipta. Jadi, secara otomatis dana punia atau sedekah yang dihaturkan adalah dilandasi oleh kesadaran dan penuh dengan ketulusikhlasan. Orang-orang seperti itu sadar dengan sesadar-sadarnya bahwa kekayaan memang diciptakan untuk disedekahkan. Bahkan yang lebih ekstrimnya lagi, orang kaya yang uangnya banyak, namun tidak pernah bersedekah disamakan dengan mayat, bedanya hanyalah ia masih bernafas dan mayat sudah tidak bernafas (Sudharta, 2009: 78-80).

Dalam kitab Sarasamuccaya juga dibahas mengenai beberapa hal yang dapat memperbesar pahala dari suatu dana punia, yaitu: 1) Désa yang berarti pembagian tanah, tanah yang subur dan sucilah yang patut untuk disedekahkan. 2) Kala yang berarti waktu yang baik untuk melakukan dana punia, yaitu utarayana atau saat-saat matahari berkisar ke arah utara. 3) Agama, yaitu pemberian ajaran pustaka suci yang menerangkan dengan mendalam perihal keagamaan. 4) Ksetra artinya orang yang diberikan sedekah adalah orang yang berkelakuan baik dan memang tepat untuk menerima sedekah. 5) Druwya berarti barang yang disedekahkan haruslah dalam kualitas yang baik. 6) Datta berarti orang yang memberikan sedekah atau melaksanakan upacara korban adalah orang yang tepat untuk itu. Dan 7) Manah berarti pikiran si pemberi sedekah tersebut haruslah tulus ikhlas. Ketujuh unsur tersebutlah yang 
membuat pahala persedekahan menjadi berkali lipat lebih besar. Pada saat melakukan dana punia, bukanlah jumlahnya yang diperhatikan, namun yang paling penting adalah tujuan dalam pemberian dana punia tersebut dan cara memperoleh sesuatu yang dipuniakan. Dana punia akan cacad apabila hanya bertujuan untuk mencari ketenaran semata, apalagi sesuatu yang disumbangkan berasal dari hasil mencuri, merampok, korupsi, maupun hal-hal negatif lainnya. Hal yang tidak kalah pentingnya adalah ketepatan kebutuhan yang diberikan saat berdana punia. Sebagai contoh: Saat seseorang merasa lapar karena belum makan selama tiga hari, hendaknya orang tersebut diberikan makanan dan minuman yang layak, bukan malahan diberikan emas batangan. Meskipun emas jauh lebih mahal dan mewah, namun dana punia tersebut tidaklah tepat diberikan kepada orang yang sangat kelaparan. Itulah yang dinamakan dana punia haruslah tepat guna (Sudharta, 2009: 81-83).

\subsubsection{Kama}

Kama secara etimologi berasal dari bahasa Sanskerta, yaitu kāma yang berarti berharap, keibaan, hawa nafsu, Dewa Cinta, Dewa Asmara, dan objek dari keinginan (Surada, 2007: 85). Kama secara umum diketahui sebagai hawa nafsu atau keinginankeinginan. Munculnya kama tentunya dipengaruhi oleh adanya indria yang dimiliki oleh manusia. Indria akan mampu membantu manusia dalam kehidupan, namun apabila indria terlalu dituruti secara kebablasan, maka yang ada adalah manusia akan menjadi budak dari nafsunya sendiri. Hal ini juga dibahas dalam Sarasamuccaya, yaitu kita harus mewujudkan sifat matinya indria. Yang dimaksud dengan sifat matinya indria adalah indria yang berguna sewajarnya tanpa adanya obsesi untuk mendapatkan kepuasan atau kesenangan yang mambutakan (indria yang terkendali). Cara untuk mencapai sifat matinya indria adalah dengan jalan tidak berangan-angan, tidak meraba-raba, dan tidak mengkhayalkan sesuatu yang dapat merangsang hawa nafsu. Dengan adanya sifat tersebut, maka seseorang tidak akan mengenang-ngenang kembali rasa nikmat yang pernah dirasakan. Kenangan akan kenikmatan dibuang jauh-jauh, sehingga tidak akan timbul nafsu untuk menikmatinya kembali dan seseorang tersebut sudah mampu menyingkirkan kainginannya akan kenikmatan tersebut.

Pada zaman sekarang, tidak dapat dipungkiri bahwa wanita merupakan objek yang selalu menantang nafsu. Bahkan dalam Sarasamuccaya disebutkan bahwa di antara semua yang menimbulkan nafsu birahi, tidaklah ada yang dapat melebihi rangsangan perempuan, karena demikian hebatnya menyebabkan kedukaan. Apalagi yang disebut dengan perempuan nakal, maka sudah pasti ia akan menyebabkan penderitaan, sehingga harus dihindari. Jangankan diajak kencan, dikenang saja perempuan semacam itu sudah tidak pantas. Selain pada pembahasan wanita nakal, dalam kehidupan saat ini sangat banyak juga para pria yang sangat hancur apabila ditinggalkan oleh wanitanya, sehingga hidup mereka menjadi kacau dan tidak karuan. Dalam hal ini, kitab Sarasamuccaya sloka 418 memberikan nasihat untuk bangkit dari rasa cinta terhadap wanita atau istilah zaman sekarang disebut dengan move on, yaitu:

Apan ikang wang malara an papasah lawan kāsihnya, göngning sihnya, makanimitta kāngénangěnani guṇanya, salwiring pālapanya, kāraṇikaa, ya ta anuwuhakèn prihati śoka santāpa ri hatinya, halanya pwa angènangěněnya, salwiring doșanya, hilang niyataṇi sihnya těke prihatinya.

\section{Terjemahan:}

Karena seseorang itu pasti menderita duka bila bercerai dengan yang dikasihinya, besar nian cinta kasihnya hingga menyebabkan selalu terkenang olehnya segala kenikmatan. Semua keistimewaannya itulah yang menyebabkan timbulnya keprihatinan, kesedihan, dan kenestapaan hati. Kalau kejelekan-kejelekannya dikenang kekurangannya diingat, tentu lenyaplah rasa cinta kasih itu. 
Dan akibatnya, lenyap pulalah kedukaan hati karena ditinggal pergi (Sudharta, 2009: 184).

Sloka Sarasamuccaya di atas mengisyaratkan bahwa sebagai seorang yang kuat, ia harus mampu melupakan segala macam kenangan manis yang pernah dilalui dengan orang terkasih, karena pada dasarnya semua itu telah berlalu dan jangan sampai seseorang masih terperangkap dalam ingatan masa lalu yang mambuatnya menjadi tidak memiliki semangat hidup, bahkan yang banyak terjadi saat ini adalah bunuh diri akibat putus cinta. Dalam hal ini, kitab Sarasamuccaya memberikan tips yang sangat ampuh untuk cepat-cepat melupakan mantan, yaitu dengan cara mengingat semua keburukan dan kelakuan jelek yang pernah dilakukan oleh mantan kekasih, sehingga akan timbul suatu pikiran bahwa ia tidaklah pantas untuk dijadikan kekasih. Dengan demikian, kita malah akan bersyukur berpisah dengannya, karena apabila hubungan terus berlanjut, maka akan terjadi hal yang lebih buruk dari saat ini.

Sebagai manusia yang baik dan berkarakter, hendaknya pengendalian terhadap pikiran haruslah selalu dilakukan, karena pikiran merupakan raja dari segala indria dalam tubuh manusia. Pikiran yang tidak terkendali dalam kitab Sarasamuccaya diumpamakan sebagai api yang menyala dan berkobar-kobar dan disiram dengan bensin. Semakin banyak bensin disiramkan ke api, maka kobaran api akan semakin besar dan ganas. Begitu juga dengan pikiran, semakin selalu dituruti nafsu birahi dari pikiran itu, maka nafsu pikiran tersebut tidak akan pernah puas atau akan selalu meminta lebih dan lebih. Sama halnya dengan godaan wanita nakal. Seorang laki-laki haruslah mampu untuk menahan nafsu dalam hal godaan wanita nakal, karena wanita nakal akan terus menggoda tanpa memandang suatu apapun seperti kutipan Sarasamuccaya sloka 428 sebagai berikut:

Tātan hana tan yogya parana, ening strī ngaranya, tan yogya mara irika, apan mamangke gatingku, kunang ika, mamangkana gatinya, mamangkana katwanganya, tātan katěkan wiweka mangkana, ikang strī ngaranya; mara juga ya, mwang tan wruh ta ya ring atuha ring anwam, tātan huninga ya ring surūpa lawan wirūpa, jalu-jalu ta pwa iki, mangkana juga lingnyan těkākèn rāganya.

\section{Terjemahan:}

Bagi seorang perempuan nakal, tidak ada yang tidak boleh didatanginya. Ia tidak akan berpikir begini: "Ah aku tidak boleh kesana karena keadaanku begini, sedang dia itu hidupnya demikian rupa dan demikian tekunnya ia". Perempuan nakal tidak akan mempunyai pertimbangan sebagai itu. Ia akan langsung menuju sasarannya dan ia tidak peduli apa itu orang tua, apa orang muda. Tidak perduli dia apakah orang itu tampan ataupun jelek rupanya. "Ia adalah laki-laki", hanya itu yang dipikirkannya ketika perempuan nakal itu ada dalam gejolak nafsunya (Sudharta, 2009: 189).

Sloka di atas menjelaskan sedemikian brutalnya wanita nakal, sehingga laki-laki harus selalu waspada dengan jalan seingin apapun untuk mencicipi wanita nakal tersebut, maka berusahalah agar tidak sampai terjerumus dalam jebakan wanita nakal, karena wanita nakal tiada lain bagaikan pukat atau jaring yang siap untuk menjebak ikanikan yang tergoda akan makanan dalam jaring tersebut. Sehebat-hebatnya ilmu pengetahuan yang dimiliki oleh Bhagawan Sukra dan Bhagawan Wrhaspati, maka wanita nakal akan jauh lebih hebat trik dan tipu dayanya, sehingga akan membuat para laki-laki menjadi tergoda, meskipun ia telah menguasai ilmu pengetahuan yang amat mulia (Sudharta, 2009: 190). Bahkan, sebanyak apapun si wanita nakal telah mendapatkan rekan untuk diajak bersenggama, ia tidak akan pernah merasa puas, malahan akan terus merasa kurang dan kurang. Oleh karena itu, apapun 
alasannya, maka seorang laki-laki haruslah mampu manahan godaan dan rayuan wanita nakal. Demikianlah hakikat kama dalam kitab Sarasamuccaya.

\subsubsection{Moksa}

Secara etimologi, moksa berasal dari bahasa Sanskerta "mokș menjadi mokșa" yang berarti kemerdekaan, kebebasan, kelepasan, pengiriman, dan pengantaran (Surada, 2007: 256). Moksa juga berarti suatu kesempurnaan (Mardiwarsito, 1986: 353). Moksa adalah tujuan akhir dari setiap orang yang memeluk agama Hindu, yaitu menyatunya atman dengan brahman, sehingga tidak akan pernah mengalami kelahiran maupun penderitaan apapun. Yang ada adalah kebahagiaan kekal abadi atau disebut dengan sat sit ananda dan dalam istilah Balinya disebut suka tan pawali duka (kebahagiaan yang tidak akan kembali kepada kedukaan). Menurut kitab Sarasamuccaya, orang yang mampu mencapai moksa disebut sebagai orang bijaksana. Orang bijaksana adalah orang yang menyadari akan hakikat kebenaran dan tidak terpengaruh dengan perasaan sedih, kecewa, bahagia, dan semua rasa keduniawian. Orang bijaksana memiliki kekuatan batin yang luar biasa, sehingga ia mampu mengarungi berbagai problematika kehidupan dengan sangat cemerlang. Orang yang bijaksana adalah orang yang mengetahui hakikat hidup dan tidak pernah dipengaruhi oleh umur tua, kulit yang keriput, keremajaan, dan semua hal-hal keduniawian. Sikap seperti itulah yang disebut dengan hati pradnyan atau hati yang bijaksana. Dengan adanya hati yang pradnyan, maka seseorang tidak akan bersedih saat menemui kedukaan, tidak akan terlalu bergembira saat menemui kesenangan, tidak mempunyai sifat marah, takut, maupun sedih, namun selalu tenang di segala kondisi (Sudharta, 2009: 223-226).

Terkait dengan orang yang bijaksana, kitab Sarasamuccaya sloka 507 dan 510 secara lebih lanjut menjelaskan sebagai berikut:

Apan ika sang tělas tuměmung kaprajňan, hilang kalangkaning jňānanira, nișkalangka pwa jňānanira, katěmu tang sattwaguna denira, sattwa kewala, tan karakětan, rajah tamah, sattwa ngaraning satah bhāwah, si uttamajn̄āna, citta sat swabhāwa, tar kakènan tṛ̣ṇādi, katěmu pwang sattwaguṇa denira, prasannātmaka ta sira, tan karakět ring śarīra, luput ring karmaphala.

\section{Terjemahan:}

Sebab ia yang telah mempunyai kebijaksanaan, hilanglah noda-noda pada hati nuraninya. Setelah hati tanpa noda, olehnya akan ditemui satwaguna, hanya satwa, tidak dicampuri oleh rajah tamah. Satwa artinya, keadaan yang penuh kebenaran. Orang yang mempunyai hati utama, pikirannya yang selalu mencari kebenaran, tidak dikuasai oleh napsu kasih dll, ditemuinyalah olehnya satwaguna itu. Ia menjadi suci murni, tidak diikat oleh badannya, terhindar dari karmaphala, buah dari perbuatannya (Sudharta, 2009: 225226).

Kunang paramārthanya, hilang ikang kleśaning awak, an pinanasan ring jn̄āna, hilang pwang kleśa, ri katěmwaning samyagjn̄āna hilang tang janma, mari punarbhawa, kadyangganing wīja, pinanasan sinanga, hilang tuwuh nika, mari masěwö.

\section{Terjemahan:}

Adapun hakikatnya, sirnalah kekotoran pada diri kita, jika dilebur oleh pengetahuan suci (jnana), sirnalah kekotoran itu. Pada saat didapati samyagnyana (pengetahuan) hilanglah penjelmaan orang itu, tidak lahir kembali. Sebagai halnya benihbenih itu jika dipanasi dipanggang, maka hilanglah daya tumbuhnya tidak berkecambah lagi (Sudharta, 2009: 227).

Kedua sloka di atas sangatlah jelas memaparkan bahwa pada dasarnya apabila seseorang mampu menjadikan dirinya sebagai 
orang yang bijaksana dan berpengetahuan mulia, maka ia akan mampu bebas dari segala ikatan duniawi dan tidak akan pernah menjelma kembali untuk menikmati penderitaan di dunia ini. Singkat kata, seseorang tersebut akan mampu mencapai moksa dan mendapatkan kebahagiaan yang tiada tara tingginya. Hal tersebut terjadi karena ia telah mencapai suatu tingkat yang disebut dengan satwaguna atau hanya guna satwa (sifat-sifat kebaikan) yang melekat dalam dirinya, sehingga tidak akan pernah lagi terbersit keinginan utuk menikmati indahnya nafsu, kemalasan, keangkuhan, kekayaan, dan lain sebagainya yang marupakan penjelmaan dari rajas dan tamas. Dengan pengetahuan suci dan kebijaksnaannya, maka ia akan mampu melepaskan semua ikatan duniawi dan akhirnya mencapai yang dinamakan moksartham jagadhita ya ca iti dharma. Demikianlah hakikat pencapaian moksa menurut kitab Sarasamuccaya.

\section{PENUTUP}

Dasar dari tujuan hidup manusia menjelma di dunia ini menurut kitab Sarasamuccaya pada hakikatnya adalah untuk senantiasa selalu mengusahakan berbuat baik dan menolong diri sendiri dari penderitaan, sehingga manusia akan mampu membayar karma buruk di kehidupan lalu dengan karma baik di kehidupan saat ini sebagai bekal menuju ke tingkatan hidup yang lebih baik. Apabila manusia mampu selalu berbuat yang baik, maka jalan untuk mencapai kebahagiaan abadi akan sedikit demi sedikit dapat terbuka. Kitab suci agama Hindu yang mengajarkan terkait perbuatan susila adalah kitab Sarasamuccaya. Salah satu ajaran susila yang terkandung dalam kitab Sarasamuccaya adalah Catur Purusartha atau Catur Carga. Ajaran Catur Warga atau Catur Purusartha yang terdapat dalam kitab Sarasamuccaya dituangkan dalam untaian sloka demi sloka yang berjumlah 517 sloka. Masing-masing bagian Catur Purusartha diuraikan dalam beberapa pembahasan, yaitu: ajaran dharma dalam kitab Sarasamuccaya diuraikan pada segmen keagungan dharma, sumber dharma, dan pelaksanaan dharma. Pembahasan tentang artha diuraikan melalui keutamaan dana punia. Ilmu tentang kama atau nafsu diuraikan dalam pembahasan kama (nafsu) dan perempuan nakal. Terakhir, ajaran kelepasan (moksa) diuraikan dalam konsep dan hakikat orang bijaksana. Keseluruhan pembahasan tersebut merupakan pedoman praktis yang mudah dipahami oleh manusia, sehingga apabila setiap orang menginginkan pencapaian tujuan hidup secara sempurna, maka sangat dianjurkan untuk mengindahkan sabda sloka-sloka Sarasamuccaya, terutama yang terkait dengan Catur Purusartha.

Pustaka suci Sarasamuccaya merupakan salah satu produk dan turunan kitab suci Weda yang sarat akan nilai-nilai kesusilaan dalam kehidupan. Buah karya Bhagawan Wararuci yang terbagi ke dalam 517 sloka tersebut sangatlah ideal bagi orangorang yang ingin mencapai suatu keutamaan hidup. Salah satu konsep yang terkandung dalam kitab Sarasamuccaya adalah Catur Purusartha atau empat tujuan hidup manusia yang terdiri dari dharma (kebenaran), artha (harta), kama (nafsu/keinginan), dan moksa (kelepasan). Aturan untuk mencapai keempat tujuan hidup tersebut diuraikan secara rinci melalui sloka-sloka maupun terjemahannya, sehingga sangat mudah untuk dipahami. Dalam kehidupan milenial yang serba modern dan praktis saat ini, kitab Sarasamuccaya sangat dianjurkan sebagai pedoman kehidupan, karena selain praktis dan mudah dimengerti, ajaran-ajaran yang terkandung di dalamnya amatlah sesuai dengan konteks kehidupan saat ini, sehingga tidak menimbulkan persepsi yang keliru. Apabila menginginkan kualitas hidup yang lebih baik, kitab Sarasamuccaya adalah hal yang penulis anjurkan untuk dibaca, dipahami, dan tentunya dilaksanakan dalam kehidupan.

\section{DAFTAR PUSTAKA}

Mardiwarsito. 1986. Kamus Jawa KunaIndonesia. Flores: Nusa Indah.

Sudharta. 2009. Sārasamuccaya Smerti Nusantara (Berisi Kamus Jawa KunoIndonesia). Surabaya: Paramita. 
Surada. 2007. Kamus Sanskerta Indonesia. Titib. 2011. Tri Sandhya Sembanghyang dan Denpasar: Widya Dharma.

Berdoa. Surabaya: Paramita.

Titib. 1996. Veda Sabda Suci: Pedoman

Praktis Kehidupan. Surabaya:

Paramita. 